\title{
Conversation Implicature in Interrogative Utterance of The Discourse of E-Commerce Business Advertisement
}

\author{
Bambang Prastio $^{1}$, Abd. Syukur Ibrahim ${ }^{1}$, Gatut Susanto ${ }^{1}$ \\ ${ }^{1}$ Pendidikan Bahasa Indonesia-Universitas Negeri Malang
}

\section{INFO ARTIKEL}

\section{Riwayat Artikel:}

Diterima: 08-03-2019

Disetujui: 23-07-2019

\section{Kata kunci:}

interrogative; conversation implicature; advertisement discourse; e-commerce

\author{
Alamat Korespondensi: \\ Gatut Susanto \\ Pendidikan Bahasa Indonesia \\ Universitas Negeri Malang \\ Jalan Semarang 5 Malang \\ E-mail: gatut.susanto.fs@um.ac.id
}

\begin{abstract}
ABSTRAK
Abstract: This research aims to describe the function of interrogative utterance contained in conversation implicature in the discourse of e-commerce business advertisement. The source of data in this research was in the form of interrogative utterance obtained in ecommerce business advertisement such as online shopping, online transportation, and drop shipping existed in YouTube. E-commerce advertisement of online shopping is an advertisement which frequently has conversation implicature. Meanwhile, online transportation advertisement and drop shipping seldom have conversation implicature. This research employed pragmatics in order to analyze the transcript data. Based on the data analysis, the researcher found out five functions of interrogative utterance, they are (1) instruction function, (2) asking function, (3) forbidding function, (4) refusing function, and (5) suggesting function. From these five functions of interrogative utterance in the conversation implicature, it can be concluded that the discourse of interrogative utterance in the advertisement of e-commerce leads to persuasive form.

Abstrak: Penelitian ini bertujuan untuk mendeskripsikan fungsi ujaran interogatif yang terkandung dalam implikatur percakapan dalam wacana iklan bisnis e-commerce. Sumber data dalam penelitian ini adalah dalam bentuk ucapan interogatif yang diperoleh dalam iklan bisnis e-commerce, seperti belanja online, transportasi online, dan pengiriman drop yang ada di youtube. Iklan e-commerce dari belanja online adalah iklan yang sering memiliki implikatur percakapan. Sementara itu, iklan transportasi online dan layanan dropshipping jarang memiliki implikatur percakapan. Penelitian ini menggunakan pragmatik untuk menganalisis data transkrip. Berdasarkan analisis data, peneliti menemukan lima fungsi ucapan interogatif, yaitu (1) fungsi instruksi, (2) fungsi bertanya, (3) fungsi melarang, (4) fungsi menolak, dan (5) fungsi saran. Dari lima fungsi ujaran interogatif ini dalam implikatur percakapan, dapat disimpulkan bahwa wacana ujaran interogatif dalam iklan e-commerce mengarah pada bentuk persuasif.
\end{abstract}

Conversational implicature will appear through the communication process when running everyday life. Conversational implicature is important to know to avoid misunderstandings in interpreting so that a smooth interaction and communication process will be obtained. Through speech, there will be one or more utterances involving the speakers and receptors. Speech events have one subject matter and are in the same place, situation, and time. (Grice, 1957) states that implicatures are used for what might be suggested, interpreted, or intended by speakers differently with what is expressed. The conversational implicature is interesting to be examined because it has hidden meanings in communication that have purpose to maintain manners and politeness of language in achieving the intentions to be delivered. (Mazzarella, Reinecke, Noveck, \& Mercier, 2018) stated that a speaker will be authoritative if the purpose of the speech is delivered indirectly so that it has a hidden meaning. Someone in communication sometimes uses speech in delivering conversation implicatures

Speech is something that is spoken and delivered to the opponent when there is a communication. Speech cannot be separated from the communication process and interaction in executing daily life in the society. Speech is the realization of sentences delivered verbally when communicating. (Carston, 2004) states that speech usually consists of a set of logical thought results and will be realized when communicating. When someone communicates, it will deliver several types of speeches (Leech, 1983; Rahardi, 2005). One of the speeches that need to be known by someone is interrogative speech. 
Interrogative speech has an important role in the communication process. The pragmatic study about interrogative speech becomes very important because seeing the related intonation, grammar and speech functions (Enfield et al., 2010). Interrogative speech is speech of questions that have the intention to ask something so that they get information from the other person. (Siemund, 2017) states that interrogative speech is speech that wants to get information

Research related to interrogative speech in conversational implicatures has been carried out by several previous researchers. One of them is (Suroso, Suwandi, \& Sumarlam, 2017) reviewed student implicature when sending messages to the lecturers. The finding shows that the form of implicature that realized through SMS (short message service) includes only verbal interrogative form. The interrogative speeches are realized in willingness request, legal requests, and information request

The disclosure of the meaning and purpose in the event of the advertising language is vary. Some are expressed in clear language so that the language of the reader or listener can understands the purpose of the ads immediately. However, there are also expressions that in language that cannot be directly understood which are called implicatures (Suroso et al., 2017). The understanding of the implicit meanings in a conversation requires the ability to interpret meaning. (Allan, 2016) stated that the meaning of a speech can be understood from the interpretation results and understanding about implicature theory

Research on conversational implicatures in advertisements has been done by several previous researchers. One of them is (Siallagan, 2015) who conducted research on implicature in advertising discourse in private television stations. Based on the research findings, the function of the advertisement is in the form of offering cheaper prices, offering product benefits, and informing the excellence given

The technology and innovation are growing in this 21 st century. Along with the number of internet users that increase, it provides benefits to find information and provide easiness in running daily activities. The development of technology and the internet has resulted in a new shopping model that uses electronic help by utilizing smartphones to shop that is $e$-commerce (Prihadi, 2017). The development of e-commerce users is increasing because the payment system is easy, saves energy and the service is satisfying. Fan, et al (2018) stated that $e$-commerce can increase intercity shopping, save time and save costs

The existence of $e$-commerce system make the producers will try to make advertising as a medium in introducing the products and services they offer. One way to introduce the products and services they offer is through the advertising on social media. Alalwan (2018) stated that social media at this time was used in advertising and marketing. One form of social media is YouTube. When open YouTube, you will see various types of advertising. YouTube is not missed being targeted by ads producers. (Deghani, Niaki, Ramazani, Sali, \& Rasoul, 2017) stated that YouTube has attracted the advertisers' attention to invest in developing media as communication and to introduce their advertising.

Interrogative speech is very important to be considered in a conversation, especially in the advertising discourse conversation. This is because people often do not understand the intended speech. Based on this, this research aims to discuss the interrogative speech contained in conversational implicatures in the discourse of $e$-commerce business advertising.

\section{METHOD}

The qualitative approach was chosen in this research. The type of research used is pragmatic research to reveal the meaning in e-commerce business advertising discourse. Then, pragmatics is used as data analysis approach that aims to guide the process of analyzing interrogative verbal forms and their functions. The research instruments used are presented in table 1.

Table 1. Research Instruments in Data Collection

\begin{tabular}{cllll}
\hline No & \multicolumn{1}{c}{ Focus } & \multicolumn{1}{c}{ Description } & Data Collection Technique & \multicolumn{1}{c}{ Source of Data } \\
\hline 1 & $\begin{array}{l}\text { Form of } \\
\text { Interrogative } \\
\text { Utterance }\end{array}$ & $\begin{array}{l}\text { The utterance which expresses statements } \\
\text { to the interlocutors with the purpose to } \\
\text { obtain certain information. }\end{array}$ & $\begin{array}{l}\text { Observation, } \\
\text { documentation, and } \\
\text { transcription }\end{array}$ & $\begin{array}{l}\text { Advertisement of E- } \\
\text { commerce Business (Online } \\
\text { transportation, Online } \\
\text { shopping, and drop shipping) }\end{array}$ \\
\hline 2 & $\begin{array}{l}\text { Function of } \\
\text { Interrogative } \\
\text { Utterance }\end{array}$ & $\begin{array}{l}\text { The purposes of interrogative utterance } \\
\text { construction which is used by the speaker } \\
\text { in order to deliver the aims of the } \\
\text { utterance to interlocutors. }\end{array}$ & $\begin{array}{l}\text { Observation, } \\
\text { documentation, and } \\
\text { transcription }\end{array}$ & $\begin{array}{l}\text { Advertisement of E- } \\
\text { commerce (Online } \\
\text { transportation, Online } \\
\text { shopping, and drop shipping) }\end{array}$ \\
\hline
\end{tabular}

The research data source was obtained through e-commerce business advertisements that were shown on advertising on YouTube. There are eight data sources which are categorized to be three types of $e$-commerce. The data sources used are presented in table 2. There are two reasons researchers choose the data source used. First, the data needed is contained in the advertisement based on a preliminary study. Secondly, the applications owned by e-commerce advertisements have been widely used by Indonesian society based on the number of downloaders. The data in this research come from the results of the transcription of the conversation into written form by adding the research context. Furthermore, the data obtained is analyzed based on the theory developed by (Miles \& Huberman, 2007). 
Table 1. Research Data Sources. Source: Playstore (2018)

\begin{tabular}{clll}
\hline No & Source of Advertisement & The Number of Downloader & Advertisement Category \\
\hline 1 & Gojek Indonesia & $50.000 .000+$ & Online Transportation \\
\hline 2 & Bukalapak & $10.000 .000+$ & Online Shopping \\
\hline 3 & OLX & $10.000 .000+$ & Online Shopping \\
\hline 4 & Traveloka & $10.000 .000+$ & Online Shopping \\
\hline 5 & Shopee & $50.000 .000+$ & Online Shopping \\
\hline 6 & Blibli & $10.000 .000+$ & Online Shopping \\
\hline 7 & Akulaku & $10.000 .000+$ & Online Shopping \\
\hline 8 & Pos Indonesia & $10.000+$ & Drop Shipping \\
\hline
\end{tabular}

\section{RESULTS}

This study found five interrogative speech functions in conversational implicature in the discourse of $e$-commerce business advertising. Each function has a diverse amount of data, these functions are presented in table 3.

Table 2. Findings of Research Data

\begin{tabular}{cllll}
\hline No & Function & The Number of Data & \multicolumn{1}{c}{ Type of e-commerce } & \multicolumn{1}{c}{ Advertisement Source } \\
\hline 1 & Instructing & 9 & Online transportation advertisement & Gojek, \\
\cline { 3 - 5 } & & Online shopping advertisement & $\begin{array}{l}\text { OLX, Traveloka, Shopee, } \\
\text { Bli-bli, Akulaku, dan Bukulapak. }\end{array}$ \\
\hline 2 & Asking & 4 & Online shopping advertisement & Traveloka \\
\cline { 3 - 5 } & & & Online shopping advertisement & Pos Indonesia \\
\hline 3 & Forbidding & 2 & Online shopping advertisement & Bukalapak dan Bli-bli \\
\hline 4 & Refusing & 1 & Online shopping advertisement & Shopee \\
\hline 5 & Suggesting & 1 & Drop shipping advertisement & Pos Indonesia \\
\hline
\end{tabular}

\section{DISCUSSION}

Based on the findings, the discussion of this research are divided into five parts based on the interrogative speech function in the discourse of e-commerce business advertising. The five functions include the function of ordering, requesting, disallowing, rejecting, and suggesting.

\section{Ordering Function}

There are nine interrogative speech data with the function of telling. One of the speeches is presented as follows.

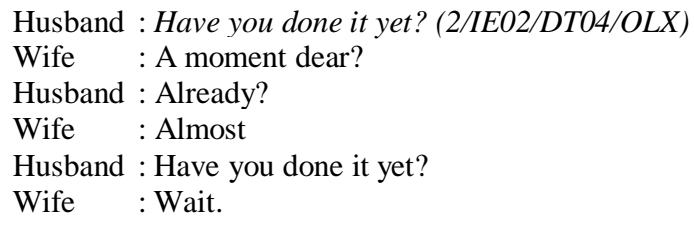

The context of the conversation occurs between the husband (speaker) and the wife (as opposed to saying) in the house. This conversation occurs when speakers and opponents say they want to go out of the house. Judging from the situation they will go to an event. The speakers' speech was motivated because they waited too long to feel bored. Speakers while waiting for opponents to say have also carried out various activities while opening the OLX application to buy something. Position opposite the speech when the speech is in the room while decorating while the speaker is in the living room.

From the speech (2/IE02/DT04/OLX) it is an interrogative speech. The interrogative speech in the conversation aim to get information about the condition or readiness of opponents in dressing. The ordering function in this speech is to tell the opponent to finish dress up so that they can immediately go to the event. The ordering function is in the interrogative speech with the aim of to make the opponent do what the speaker wants. (Siemund, 2017)stated one of the functions of interrogative speech is the ordering function. 


\section{Requesting Function}

Four interrogative speech data were found with the function request. One of the speeches is presented as follows.

Bejo : Eat something Bli Bos (take a large portion of rice and satay)

Bli Bos : Oh, ya ya ya (wondered at the portion of Bejo's food). You don't go home, Jo?

Bejo : Hehehem... I don't Bli Bos.

Bli Bo : Why?

Bejo : This problem (demonstrate the fingers that symbolize financial problems). I miss my mother and my sister. Here they are, this is my sister, and this is my mother Bli Bos (showing family photos taken from the wallet)

Bli Bos : Loh... (amazed at seeing Bejo quickly finish his food)

Bej : You don't eat Bli Bos? (2/IE02/DT05/TVL) (pointing to the food)

Bli Bos : Hmm... (thrust to Bejo)

The context of the conversation occurred between Mr. Bejo (speaker) and Bli Bos (opponent) who is the boss where the child worked. This conversation happened by telephone. Speakers in the village do not understand the purchase of airplane tickets, so the opponents say who bought tickets through the Traveloka application. The opponent spoke to the speaker as a reward because Bejo could not go home and was busy working when the Eid al-Fitr is near. The interpretation of asking is proven at the end of the conversation that the opponent informs that he have bought a ticket.

From the speech (2/IE02/DT05/TVL) it is an interrogative speech with the purpose of getting information. The interrogative speech in the conversation were asking about the food to the other person that was not spent. The speech function in the conversation is asking. The asking purpose in the interrogative speech is to ask for the food to the other person that is not ate by him. Often to get something, someone uses interrogative speech. The use of interrogative speech in communication is difficult to define as an effective form but interrogative speech is sociologically effective or communication to influence opponents so that they get something when asking for it (Frank, 1990).

\section{Disallowing Function}

Two interrogative speech data were found with the disallowing function. One of the speeches is presented as follows.

Ringgo : Bojo. Where are you going?

Istri : Give this opor to neighbor.

Ringgo : Are you sure? How if it tastes weird? (2/IE02/DT10/BLI)

Istri : Yesterday, you said it's delicious while the seasoning was wrong, right? Just calm down, it's definitely delicious, this time I see the recipe on Blibli.com.

The context of this conversation occurred between the husband (speaker) and the wife (opponent) in the backyard of the house near the kitchen when the opponent said they were going to deliver food to one of the neighbors. This conversation was caused by the previous food made by the opponent was not delicious. Speakers feel that the food is not delicious that they he afraid if the neighbor who is given the food thinks that the opponent is not good at cooking and is disappointed with the taste of the food. Speakers when these conversations express his expressions like doubting the actions of the opponent.

From that speech (2/IE02/DT10/BLI) it is an interrogative speech with the purpose of getting information about the actions that the opponent wants to do. the function of the interrogative speech is the disallowing function. The purpose of interrogative speech with the function is to disallow the opponent to give food to their neighbors. The disallowing function found from the data is in accordance with the opinion (Prayitno \& Joko, 2011) which stated that the disallowing function is used by someone to prevent the opponent to do something.

\section{Rejecting Function}

One interrogative speech data with rejecting function was found. The speech is presented as follows.

Wife : (while holding the cellphone) Pa, let's go to Bali.

Husband : (a little choked when drinking and showing a lazy expression) Ha? Is there any affordable ticket? (2/IE02/DT13/SHP)

Wife : (open the google application) Here you go pa (showing the cellphone to the husband) the price and also the time are right (then seeing the husband).

Husband : (see the wife for a while then look away) I let go.

The context of this conversation occurs between the husband (speaker) and the wife (opponent) in front of the house while reading the newspaper, drinking tea, and seeing the children who are playing. During this conversation the wife played cellphones to see ticket prices and hotels in the Shopee application. After seeing that the ticket and hotel prices are cheaper because there is a promo, the speaker invites opponents to say to go to Bali. When the speaker conveyed the invitation to go to Bali, the opponent said choking while drinking tea and also the expression on his face changed like he was not agree with the invitation. From the speech (2/IE02/DT13/SHP) is an interrogative speech with the aim of getting information about ticket prices and hotels 
that are in accordance with their financial to go to Bali. The function of the interrogative speech in the conversation is to reject. Meaning of the function refused in the conversation is to reject the wife's invitation to go on vacation to Bali. Interrogative speech with refusing functions are sometimes used by someone not to do what the opponent wants. Urbanik \& Svennevig (2019) stated that through interrogative acts the function is to refuse and expect opponents to accept the rejection.

\section{Suggesting Function}

An interrogative speech data was found with the suggesting function. The speech is presented as follows.

$\begin{array}{ll}\text { Man } 1 & \text { : Hai guys (waving hands) } \\ \text { Man } 2 & \text { : Hai bro. } \\ \text { Woman 1 } & \text { : Hai Tama. } \\ \text { Man 1 } & \text { : Miss (Waving hands). } \\ \text { Waitress } & \text { : As usual? (2/IE03/DT16/KP) } \\ \text { Man 1 } & \text { : Yes, as usual. } \\ \text { Waitress } & \text { : Okay Sir. }\end{array}$

The context of this conversation occurs between the waitress (speaker) with man 1 (versus speaking) and friends from opponents in a cafe they often visit. The speech actors in this conversation already have closeness proven when opponents visit the cafe where the speaker works and the speaker already knows the food that is often ordered by the opponent without asking.

The speech data (2/IE03/DT16/KP) is an interrogative speech with the purpose of getting information about the food that ordered by the speech opponent. Interrogative speech in this conversation have the function of suggesting. The purpose of suggesting this conversation is to suggest the speech opponent to order food that is usually ate by the opponent when eating at the place. Some functions of interrogative speech are informing and suggesting (Siemund, 2017).

\section{CONCLUSION}

Based on findings described, it can be concluded that the interrogative speech function in e-commerce business advertisements is influential or persuasive based on the purpose of the advertising world. There are five interrogative speech functions in the e-commerce advertising discourse which include the function of telling, asking, disallowing, refusing, and suggesting. The interrogative speech function is often used by the types of e-commerce advertising online shopping and rarely found in the types of e-commerce transportation online advertising. The interrogative speech functions are found in the types of e-commerce advertisements online shopping and goods shuttle. The function of interrogative speech in disallowing and rejecting is only found in e-commerce advertisements online shopping. The interrogative speech function suggests that it is only found in the types of e-commerce advertisements between goods shuttle. As seen from the data, the results of the interrogative speech leads to the characteristics of persuasive speech which aims to influence the other person. To the producers of advertisements, the results of this research can be used as a reference and input in using the language and choice of words used by ad producers. Meanwhile, other researchers can be used as references in researching e-commerce advertisements with other pragmatic studies.

\section{REFERENCES}

Alalwan, A. A. (2018). Investigating the Impact of Social Media Advertising Features on Customer Purchase Intention. International Journal of Information Management, 42(April), 65-77. https://doi.org/10.1016/j.ijinfomgt.2018.06.001

Allan, K. (2016). Contextual Determinants on the Meaning of the Word. Springer Plus, 5, 1-11. https://doi.org/https://doi.org/11.1016/j.springer.2016.11.011

Carston, R. (2004). Thoughts and Utterances: The Pragmatics of Explicit Communication. Lingua, 114, 621-628. https://doi.org/10.1016/S0024-3841(03)00035-4

Deghani, Niaki, M., Ramazani, M. K., Sali, I., \& Rasoul. (2017). Evaluating the Influence of Youtube Advertising for Attraction of Young Customers. Computers in Human Behavior, 69, 165-172.

Enfield, N. J., Stivers, T., \& Levinson, S. C. (2010). Question-Response Sequences in Conversation Across Ten Languages: An introduction. Journal of Pragmatics, 42(10), 2615-2619. https://doi.org/10.1016/j.pragma.2010.04.001

Fan, J., Tang, L., Zhu, W., \& Zou, B. (2018). The Alibaba Effect: Spatial Consumption in Equality and the Welfare Gains from E-commerce. Journal of International Economics, 114, 203-220. https://doi.org/10.1016/j.jinteco.2018.07.002

Frank, J. (1990). You Call that a Rhetorical Question? Journal of Pragmatics, 14(5), 723-738. https://doi.org/10.1016/03782166(90)90003-V

Mazzarella, D., Reinecke, R., Noveck, I., \& Mercier, H. (2018). Saying, Presupposing and Implicating: How Pragmatics Modulates Commitment. Journal of Pragmatics, 133, 15-27. https://doi.org/10.1016/j.pragma.2018.05.009

Miles, M. B., \& Huberman, A. M. (2007). Analsisis Data Kualitatif. Jakarta: UI Press.

Prayitno, \& Joko, H. (2011). Kesantunan Sosiopragmatik. Surakarta: Universitas Muhammadiyah Press.

Prihadi, S. D. (2017). Peta Persaingan Situs E-Commerce di Indonesia. CNN Indonesia. 
Rahardi, K. (2005). Pragmatik Kesantunan Imperatif Bahasa Indonesia. Jakarta: Erlangga.

Siallagan, S. C. (2015). Analisis Implikatur dalam Wacana Iklan di Stasiun Televisi Swasta. Skripsi tidak diterbitkan. Universitas Negeri Medan, Medan.

Siemund, P. (2017). Interrogative Clauses in English and the Social Economics of Questions. Journal of Pragmatics, 119, 1532. https://doi.org/10.1016/j.pragma.2017.07.010

Suroso, E., Suwandi, S., \& Sumarlam, S. (2017). Politeness Implicature on Short Message Service (SMS) Text Written by College Students Sent to Their Lecturers as A Development Media of Affective Assessment in Higher Educations. Proceedings of the 4th Asia Pacific Education Conference (AECON 2017), 109(Aecon), 77-82. https://doi.org/10.2991/aecon-17.2017.17

Urbanik, P., \& Svennevig, J. (2019). Managing Contingencies in Requests: the Role of Negation in Norwegian Interrogative Directives. Journal of Pragmatics, 139, 109-125. https://doi.org/10.1016/j.pragma.2018.10.014 